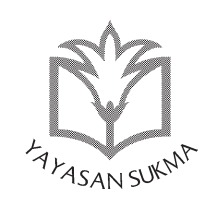

SUKMA: JURNAL PENDIDIKAN

ISSN: 2548-5105

Volume 1 Issue 1, Jan-Jun 2017, hlm. 177-196

\title{
SUPPORTING TEACHERS' LEARNING USING SCHOOL INFORMATION SYSTEM
}

\section{Satia Prihatni Zen}

Sekolah Sukma Bangsa Bireuen, Aceh, Indonesia

email: satiazen@gmail.com

\section{Abstrak}

Sistem Informasi Sekolah saat ini telah lazim digunakan oleh banyak sekolah dan otoritas pengelola pendidikan untuk membantu pengelolaan data sekolah, mulai dari data perkembangan siswa hingga data keuangan. Selain pengelolaan data, system informasi sekolah dapat menunjang pengembangan kapasitas guru dan kolegialitas dalam ruang lingkup sekolah. Hal inilah yang menjadi salah satu pengalaman Sekolah Sukma Bangsa dalam menerapkan Sistem Informasi Sekolah Terpadu Online (SISTO) untuk mendukung efisiensi serta akuntabilitas dalam pengelolaan data yang baik. Artikel ini menjelaskan bagaimana penerapan SISTO mendukung pengembangan kapasitas guru melalui 
kegiatan belajar yang terintegrasi dalam kegiatan guru sehari-hari. Hal ini dimungkinkan dengan adanya integrasi aplikasi dalam system serta fitur yang mendorong guru untuk melakukan "reflective practices." .Kegiatan-kegiatan tersebut mencakup refleksi guru, kolaborasi dalam menyelesaikan masalah, pembuatan keputusan berbasis data serta evaluasi guru berbasis SISTO. Artikel ini bertujuan memberikan gambaran singkat mengenai proses pengembangan kapasitas yang ditunjang oleh system informasi.

Kata Kunci: sisteminformasi sekolah; pengembangan kapasitas guru; pembelajaran guru.

\section{Introduction}

Teacher professional development is one of the cornerstone for improving learning process in the school. On-going development for teachers throughout their career account for significant improvement for students learning. Borko (2004) emphasized on the importance of teacher professional development and how it influence students learning and improve instructional design, although little is known on how the influence occur and what factors account for it. In Indonesia, teacher professional development mostly done through training and workshops conducted by Ministry of Education Local Office, teacher working groups or some other private provider. Due to teachers' certification policy, there was an increase awareness for teachers to find professional development program independently although most are still easily accessible in urban areas (Sumintono \& Subekti, 2014).

However aside from access challenge, some Professional Development (PD) activities available today deemed to be ineffective in supporting teachers on the job. According to Sumintono and Subekti (2014) the following reasons are factors to ineffective PD in Indonesia:

- Irrelevant materials to students learning (King \& Newman, 
2001)

- Teachers have no influence over training substance and process

- Overreliance to external funding led to unsustainability of inservice programs (Nielsen, 2013).

Based on research in teacher professional development, it is known that teachers learn from--among other things-- experience, deliberate practice and collaboration with colleagues (Meirink, Meijer, \& Verloop, 2009). A lot of teachers' tacit knowledge transferred through informal talks and discussion during breaks between classes or down time between school activities but also from solving problem together.

Various methods to support informal learning, ranging from arranging physical space to encourage meetings and talks to creating special time for every teacher can gather within the week, have been used by schools. However with the emergence of technology, a new way to engage with other teachers have been discovered and started to gain wide acceptance to support teaching and learning. There are various technological platform available to create forums for teacher online and they are supporting teacher through online publication access, sharing of information, online discussion forum even having online collaboration. According to a report by National Staff Development Council in 2001, ICT as medium of professional development plays the following roles:

- Modify learning environment;

- Provides alternative structures and media for reflecting, communicating, and acting;

- facilitates modeling and visualization;

- allows for construction and discovery of knowledge;

- expands access to information, networks, people, and ideas;

- increases the flexibility of time and places for learning; and

- provides significant resources.

Hence, ICT is one versatile and flexible tools for teachers' 
professional development. Its easy access and availability provide incentives for schools to utilize ICT for teaching and learning but also supporting teachers improvement.

This paper is intended to describe briefly how School Information System, as an ICT tools originally used to manage data, can actually support teacher learning through its applications. This article might also serve as a snapshot on how ICT can be used and integrated into teachers' daily activities. Hopefully this will start a discussion on how School Information System available today can serve as supporting tools in school-based teachers professional developments.

\section{School Information System (SIS) and SISTO}

The awareness of data complexity and large data quantity to be manage by the school required an Information System to be implemented early on. Technology in the form of School Information System (SIS) is actually used in Sekolah Sukma Bangsa to support this purpose. SIS in the school used since the beginning of the school commencement in 2006. The school build in the aftermath of tsunami and cater students who are victims of tsunami and conflict. It consists of elementary, Junior High and Senior High school and provide dormitory for older students. Data administration and utilizing it for decision making for Sukma Bangsa Schools are part of schools mission to create effective and transparent school management.

School Information System (SIS) briefly described as an information system based on one or more computers, consisting of a database and one or more computer applications, enabling the user to record, process, retrieve, output, and distribute data (Visscher, 2001). SIS in Sukma Bangsa School is aptly named SISTO (Sistem Informasi Sekolah Terpadu Online) or Online Integrated School Information System, the name refer to its integrated applications and online based access. SISTO consists of 13 applications which is integrated to each other, the data flow from each application is illustrated in Figure 1. 


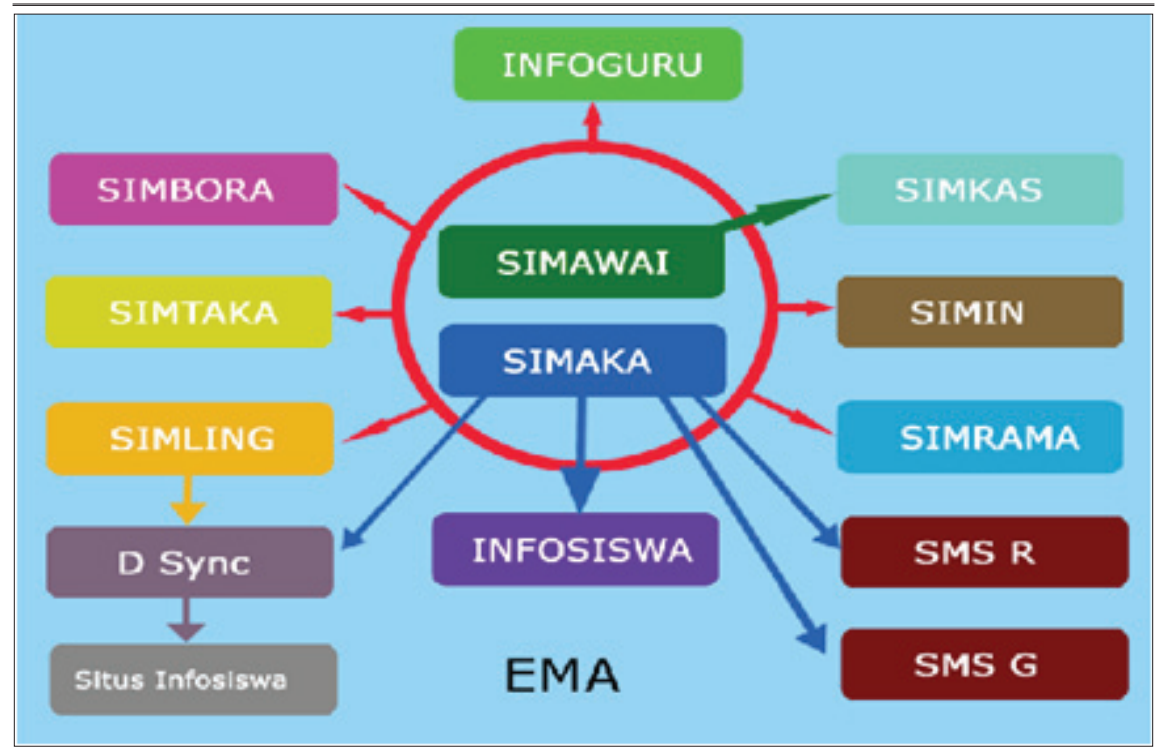

Figure 1: Data Flow Framework SISTO

These applications are used by various users in the school based on their position and department. The applications are managing both quantitative and qualitative data. The quantitative data includes statistics on students and teachers, grades, financial information, etc. While the qualitative data includes teachers description about session, students' counselling process as well as class project description and teachers reading logs.

The idea of teacher learning do not initially featured as one of the main objectives for implementing the system in Sukma Bangsa School. However after ten years implementing the system, SISTO actually supports teacher learning because:

- it supports teachers reflection,

- it encourages teachers collaboration

- It assist with data-based decision making

- It is integrated to Teachers Performance Evaluation.

Learning occur through practices of analysing their reflections on Info Guru which then being used to informed teachers 
of learning progress. While collaboration between teachers occur due to the nature of the system which require teachers to collaborate on various aspects of teaching such as assessment, class projects, team teaching and so on. Data-based decision making happened when teachers conduct analysis on data about their own teaching and other learning activities which is available online in the system. Teachers' development is encourage through daily practices of learning through some features in the Teacher Performance Module.

SISTO is gathering data on a daily basis from various sources. Therefore if it is used consistently, it will provide detailed description on classroom dynamics as well other schooling processes that will inform teachers about students' needs and progress. "Situative Perspective" as one perspective of teachers learning is actually complemented by SISTO. "In this perspective, teacher learning occurs in many different aspects of practice, including classroom, school communities, professional development workshop and training" (Borko, 2004). SISTO enable teachers to gather and analyse information from various activities conducted by teachers on a daily basis, therefore it might serve as a powerful tool for teacher learning.

\section{Teacher reflection through SISTO}

SIMAKA is one of the most integrated applications in SISTO, it is connected to various other applications such as Info Guru, Info SISWA, EMA, Library Management Applications, Dormitory Management Applications and Laboratory Management Applications. Data put into the SIMAKA applications will also be used in those applications in various degrees, for example students' data will be used in library and dormitory as well as counseling applications. For academic process, SIMAKA manages various data such as:

1. Students personal information: name, age, parents' information, family background

2. Students' registration information 
3. Schedules for teachers and classroom assignment

4. Academics Calendar and internal activities schedule

5. Content and syllabus information

6. Students attendance

7. Teachers attendance

8. Description on classroom activities and students behaviors

9. Extracurricular activities

10. Grades and types of classroom assessment and examination 11. Students statistics such as absences, grades and behaviors

The application will then assist teachers and principals in creating various reports such as:

1. Teaching session reports, includes topics, activities, short description

2. Students attendance, overall and subject-based

3. Teachers attendance, overall and subject-based

4. Students' Progress Report

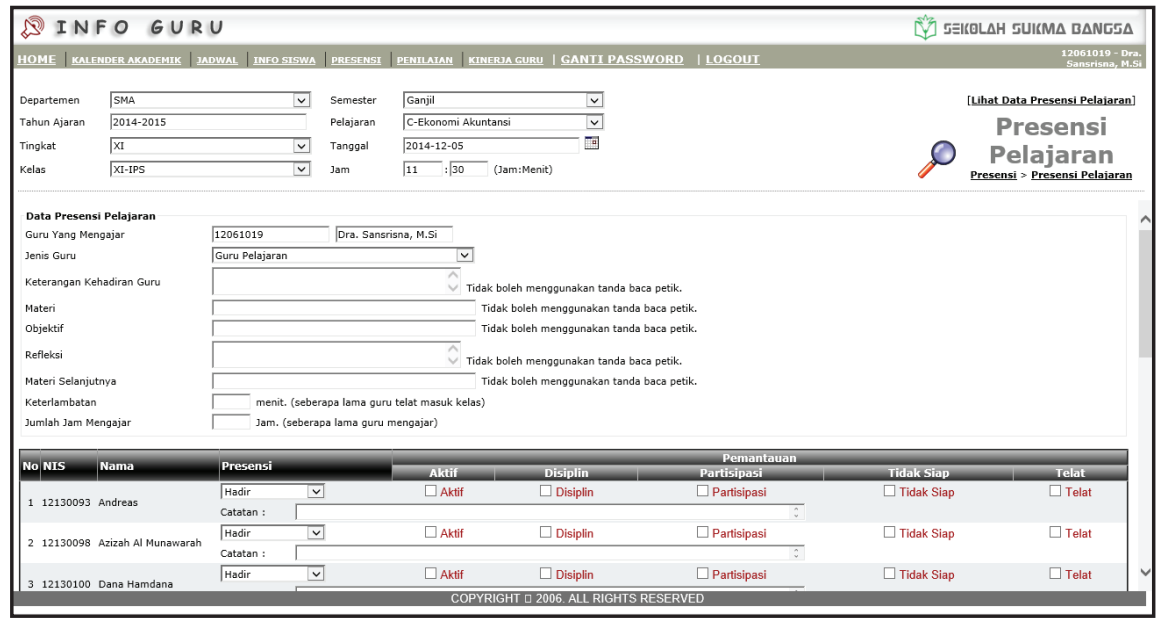

Figure 2: Presensi Pelajaran Screenshot 
Teachers are one of the most frequent users of this applications. Teacher will be able to access the SIMAKA through Info Guru page. In this page, teacher will put data on classroom process such as session description and assessment as well as notes on students' behavior and reactions.

Teacher used SISTO in a daily basis because they put in their classroom data after they conducted class sessions in their Info Guru account, specifically in "Presensi" page. Through this page, teacher will input information on topics, attendance, objectives of the session, as well as notes on students. This data will later be used to create reports on teacher attendance, teaching logs reports and student attendance reports.

The reflection from teachers about a certain session will be put into "Refleksi" section and their observation on each student can be put into "Catatan" section under each student's name (refer to Figure 2). Putting their reflection in the system help teacher to articulate their thoughts about the classroom process. "By committing reflective thinking to paper or computer, it is possible to step out of the (learning) process and engage in observing and evaluating preceding performance and learning" (Wopereis, Sloep, \& Poortman, 2010). Some teachers found this activities useful to help them understand their actions and students' responses. The excerpts from some teachers might shed lights on types of information that teachers put into their reflection (Figure 3)

In their reflections, teachers write information on topics, activities, students' reactions on the activities and follow-up activities in the next class responding to the students' needs. In some cases, teachers even acknowledge their own tardiness and the cause, as well as their anticipation for this delayed (refer to Figure 3). This reflection help teacher to be more organized in their own teaching sequences and also able to respond to students' need in a timely manner. Teachers able to assess students and record it accordingly as well as analysing their progress. This process will encourage teacher to conduct differentiated instructions through 


\begin{tabular}{|c|c|c|c|c|}
\hline 27 & 2016-01-20 & $07: 30: 00$ & \begin{tabular}{|l|} 
Guru \\
Pelajaran
\end{tabular} & \begin{tabular}{|l|} 
Materi: Praktikum Larutan Elektrolit dan nonelektrolit \\
Objektif: Mampu mengidentifikasi larutan elektrolit dan nonelektrolit \\
Refleksi: Siswa bekerja dalam kelompok kecil, mereka diminta mengidentifikasi \\
larutan berdasarkan daya hantar listriknya. setelah mengamati siswa diminta \\
menggambar hasil pengamatannya pada lembar kerja. siswa belajar penuh \\
semangat dan aktif berdiskusi dalam kelompoknya. pada akhir pembelajaran \\
siswa diuji dengan satu pertanyaan terkait praktikum yang dilakukan \\
Rencana: Bentuk Molekul \\
Keterangan Kehadiran: Hadir \\
\end{tabular} \\
\hline 43 & 2015-09-16 & $07: 30: 00$ & \begin{tabular}{|l|} 
Guru \\
Pelajaran
\end{tabular} & $\begin{array}{l}\text { Materi: Lanutan presntasi, penguatan Konsep model atom dan Ujian Tulis } \\
\text { Objektif: Uji pemahaman siswa } \\
\text { Refleksi: Guru hadir terlambat } 20 \text { menit, karena ketika berangkat ke sekolah } \\
\text { mendapatkan musibah atau kecelakaan. sebelum guru hadir siswa diminta } \\
\text { belajar mandiri, dan } 7.50 \text { KBM langsung dimulai dan siswa-siswanya sudah } \\
\text { sangat siap untuk memulai presentasi. Pembelajaran efektif, siswa } \\
\text { mempersiapkan bahan presentasi dengan baik. siswa juga dapat memahami } \\
\text { konsep dengan baik. setelah semua kelompok selesai presentasi guru kembali } \\
\text { memberi penguatan. } 20 \text { menit terakhir diberikan kuis untuk menguji pemahaman } \\
\text { siswa } \\
\text { Rencana: Konfigurasi elektron } \\
\text { Keterangan Kehadiran: Hadir }\end{array}$ \\
\hline 39 & 2015-11-09 & $10: 30: 00$ & \begin{tabular}{|l|} 
Guru \\
Pelajaran
\end{tabular} & $\begin{array}{l}\text { Materi: Sifat Keperiodikan Unsur } \\
\text { Objektif: Mampu menjelaskan sifat keperiodikan unsur } \\
\text { Refleksi: Materi ini sudah pernah dijelaskan sedikit pada pertemuan sebelumnya } \\
\text { dan siswa sudah ditugaskan untuk membuat ringkasan. oleh karena itu pada } \\
\text { awal pertemuan kali ini siswa di tes dengan } 3 \text { soal kuis. Dari hasil tes yang } \\
\text { didapat ternyata masih banyak siswa yang bingung tentang konsep sifat periodik } \\
\text { sehingga siswa diberikan pemahaman konsep kembali dengan menjelaskan } \\
\text { semua jawaban dari soal kuis, selanjutnya diberikan soal latihan dan diminta } \\
\text { untuk menjawabnya secara berpasangan. guru menjelaskan } 5 \text { sifat periodik, } \\
\text { yaitu sifat Jari-jari, logam, basa, reduktor dan elektropositif. selanjutnya } 3 \text { sifat } \\
\text { lainnya yaitu Afinitas elektron, energi ionisasi dan elektronegatif diminta siswa } \\
\text { sendiri yang menemukan konsepnya. } 75 \% \text { siswa dapat mengaitkan hubungan } \\
\text { ketiga sifat yang ditugaskan dengan jari-jari atom dan dapat menarik kesimpulan } \\
\text { sifat keperiodikan } \\
\text { Rencana: Periode dan Golongan } \\
\text { Keterangan Kehadiran: Hadir }\end{array}$ \\
\hline
\end{tabular}

Figure 3: Excerpts from Teachers Reflection

creating different type of interventions and assistance needed by the student. Assistance for students might occur in the form of one-on-one tutorial, while advance level activities will be created for those who need extra challenges in the classroom. These types of reflection is a significant part of teacher learning that will in turn improve instructions and students learning.

\section{Teacher collaboration through SISTO}

Collaboration is an integral part of SISTO, because each application is integrated to each other and data will be shared within applications to be used for various purposes. Collaboration do not come easily for some teachers, the solitary nature where teacher usually teach on their own in the classroom create a type of 'wall' where teacher might feel defensive on any criticism or suggestion. One way to reduce this isolation through School Information System is by integrating some features that will require teacher to work together for data gathering and 
analysis. One type of collaboration occur through SISTO is when teachers collaborate to formulate assessment framework that will create Students Progress Report after each semester.

Assessment procedures and standards usually formulated by teachers' subject group. Teacher will be able to determine the assessment framework together with teachers teaching the similar subjects. The procedures will include the modes of assessment and the weight assigned for each assessment tools used. Assessment framework will include information such as content, methods of assessment, grade criteria \& standard, as well as weight and percentage for each assessment method. These information will be keyed into the Academic Management Module (Sistem Informasi Manajemen Akademik,SIMAKA). Chemistry assessment framework will be used as a sample in this article (refer to Figure 4). The framework describe how Chemistry subject will use assessment in their subjects through various instruments. Normally there are two major exams namely Middle term examination (UTS) and Final examination (UAS) in Chemistry. There are also daily assessment which include: homework, topic exam, pop quiz, practices and notes. SIMAKA application will then calculate each grades based on the weight assigned previously and assist teachers in formulating grades assigned for each students in every subjects at the end of every semester.

\begin{tabular}{|c|c|c|c|}
\hline \multicolumn{2}{|c|}{ e http://lhoks.sukmabangsa.sch.id/simaka/... } & $-\square$ & $x$ \\
\hline \multicolumn{4}{|c|}{$\begin{array}{l}\text { Departemen : SMA } \\
\text { Nama Pelajaran : C-Kimia (Sarlivanti, S.Pd., M.Pd) }\end{array}$} \\
\hline No & Nama Jenis Penilaian & Bobot & \\
\hline 1 & UTS & 2 & \\
\hline 2 & UAS & 2 & \\
\hline 3 & UH & 3 & \\
\hline 4 & PR & 1 & \\
\hline 5 & Quiz & 2 & \\
\hline 6 & Lat & 2 & \\
\hline 7 & Catatan & 2 & \\
\hline 8 & Tugas & 0 & \\
\hline
\end{tabular}

Figure 4: Assessment Framework for Chemistry Screenshot 


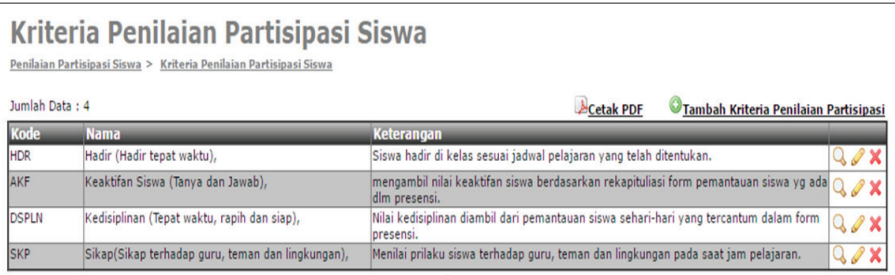

Figure5: Affective Assessment Framework

Assessment framework used in one school year will then be evaluated by teachers' group. They can modify their assessment method and the weights assigned in each activities. From the example of assessment framework above, Chemistry teachers formulated it in such a way to encourage students engage in learning process rather than focusing on one-shot examination. The daily assessment conducted through Quiz, Catatan, Ujian Harian and Latihan conducted during the learning process get a total weight of 9 out of 14 . This is signify that daily assessment during the process will contribute considerably to students' overall grade. In turn it will encourage students to be actively involved throughout the process of learning. The variety of assessment tools used throughout the process ensured that students with varied abilities will be accommodated. The overall grade will not depend solely on written examination to get good grades. Each groups of subjects create their own assessment standard and provide rationale for each modification.

Aside from academic assessment, teachers also create checklist for behavior observation in the classroom. The behaviours observation as part of assessment for each subjects will also benefit from using systematic assessment framework in SISTO by providing behavior checklist that can assist teachers in their observation. During formulation phase, teachers will also discuss the behavior indicators which reflect school values that are going to be supported in the school process. And this observation will help teachers more aware of students' responds and challenges and act as source of data for affective assessment. The following is sample of indicators for behavior indicators: 
This collaboration serve as a learning process for teachers and the learning occurs as part of problem solving for teachers' daily practices. This is in line to an experiment done by Meirink, Meijer \& Verloop in 2009, where they found that teacher often report to learn by individual reflection or by consulting with colleagues in challenging or problematic situations. By creating assessment framework with their colleagues, teachers learn from each other's experiences when they collaborate. These types of collaboration also ensure that problem solving is done collectively using groups' knowledge and experience rather than individual.

Collaboration and information sharing is a common theme in current educational improvement. Collaboration resulting from data use can benefit teaching faculties beyond one-to-one relationships. (Wayman, 2005). Collaboration through SISTO in creating assessment framework by teachers from the same subjects creates opportunity for sharing and learning from each other's experiences. This process also create benchmark for indicators that facilitate comparison within subjects as well as openness in assessment which normally kept as individual prerogative of individual teachers. This transparent assessment framework and open data support collegiality to ensure objectivity in assessment.

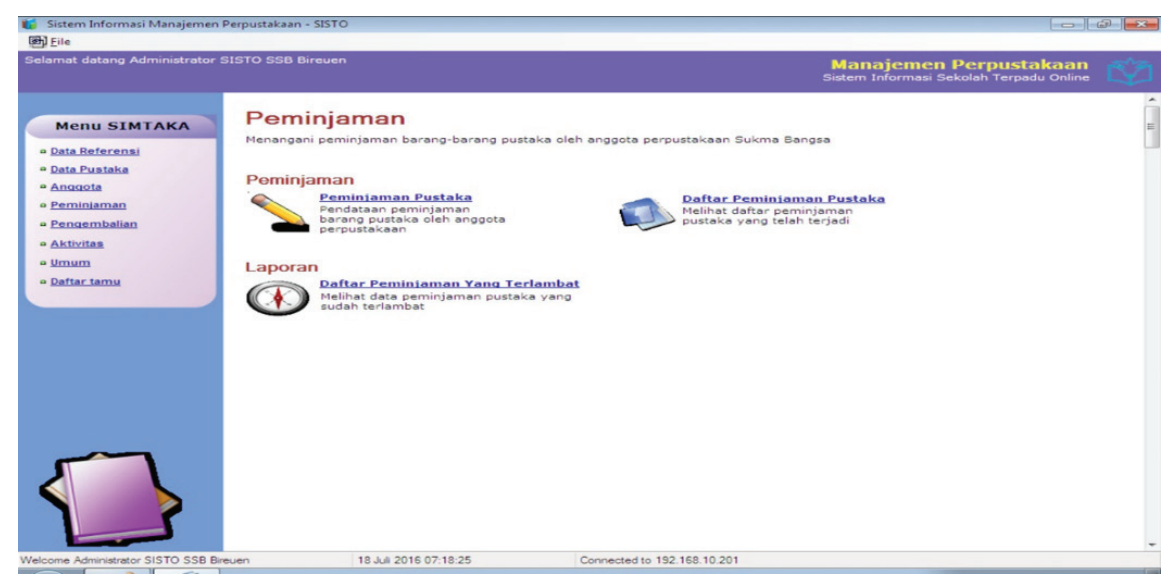

Figure 6: Screenshot of SIMTAKA 


\section{Teachers' data-based decision making}

Most teachers rely on their own memory in creating decision done in daily basis, monthly or even semester. However "the advent of educational data analysis tools represents a new opportunity to provide access to large amounts of student information that will facilitate more informed decision making and improve school performance" (Wayman, 2005). SISTO supports teachers and help them becoming more familiar with data gathering, analysis and use them to make better decisions.

One practice that demonstrate how data helps teachers and school managers to make better decisions can be seen on how they create activities to support reading culture in Sukma Bangsa School. One application namely SIMTAKA (Sistem Informasi Manajemen Perpustakaan, Library Information Management System) provides data on library collection and books-borrowing pattern that lead to reading activities in school.

\section{Jumlah Pemakaian Perpustakaan Sebagai Sumber Belajar (Juli 2014 - Juni 2015)}

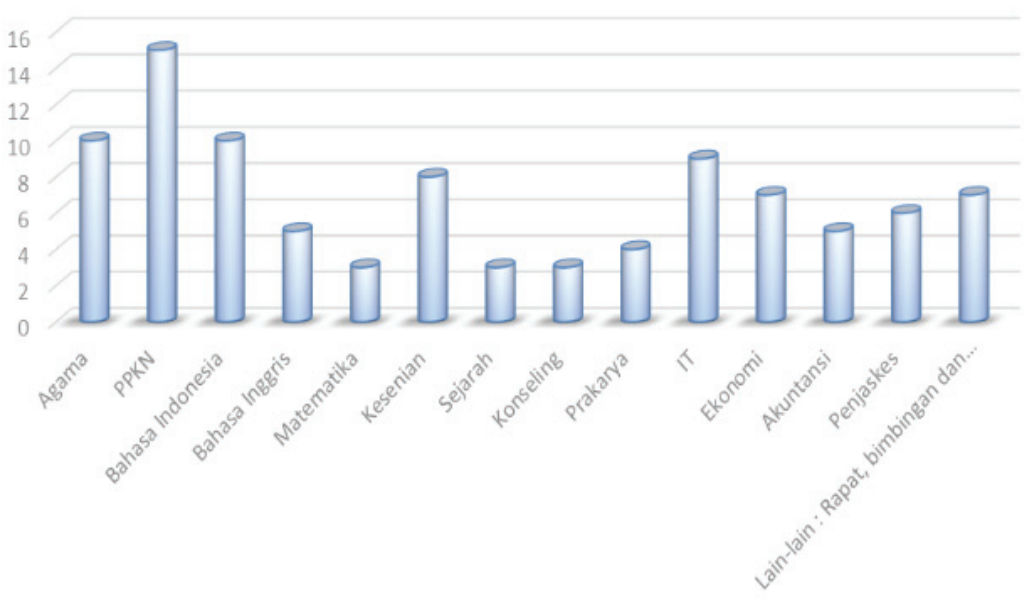

口Jumlah Pemakaian

Figure 7: Data on Library as Learning Resource Centre 
Based on the data in SIMTAKA, interesting pattern occur from data on Library use as Learning Resource and Books Borrowing by Students (Figure 7).

Graphs in Figure 7 indicates that there are not enough subjects using Library as source of learning in their daily activities. According to School Librarian, library mostly used as classroom substitute, but utilizing library collection and information beyond textbook borrowing in learning is still rare. There is a need to inform students and teachers alike on various purposes that library might serve as well as learning activities that will used library resources. This will require collaboration between teachers and School Librarian to plan learning activities that support reading and writing as well as using library collection optimally.

Figure 8 displays the quantity per students borrowing in our school and it indicates that students borrowing quantity is mostly below 20 books per year, an average of two books a month.

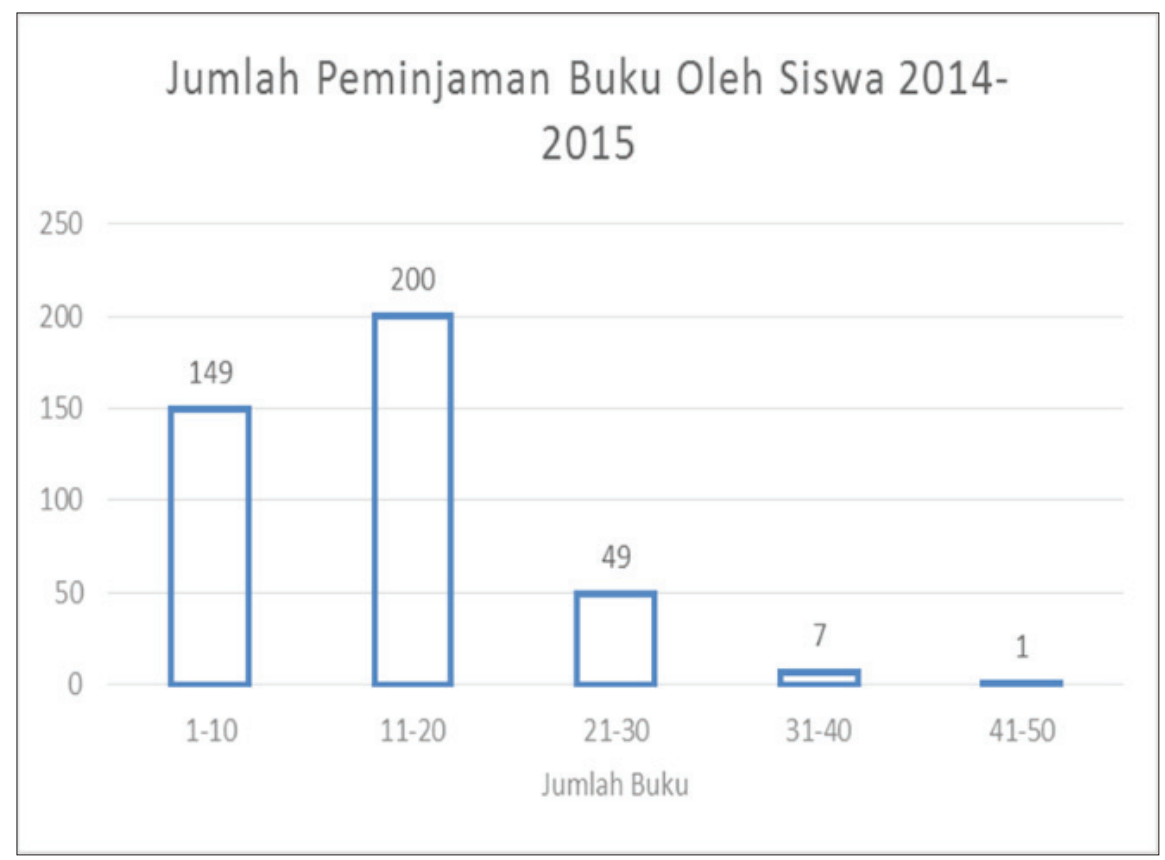

Figure 8: Data on Library Book Borrowing 


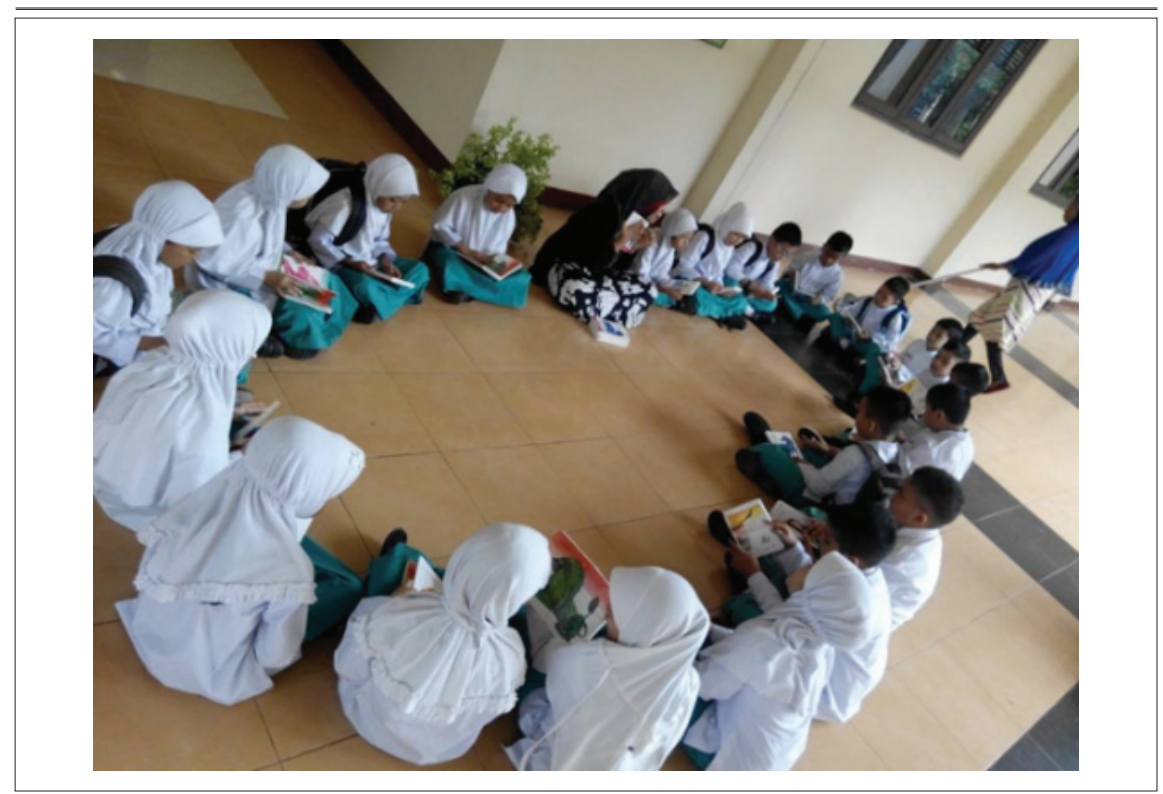

Figure 9: Students reading circle activity

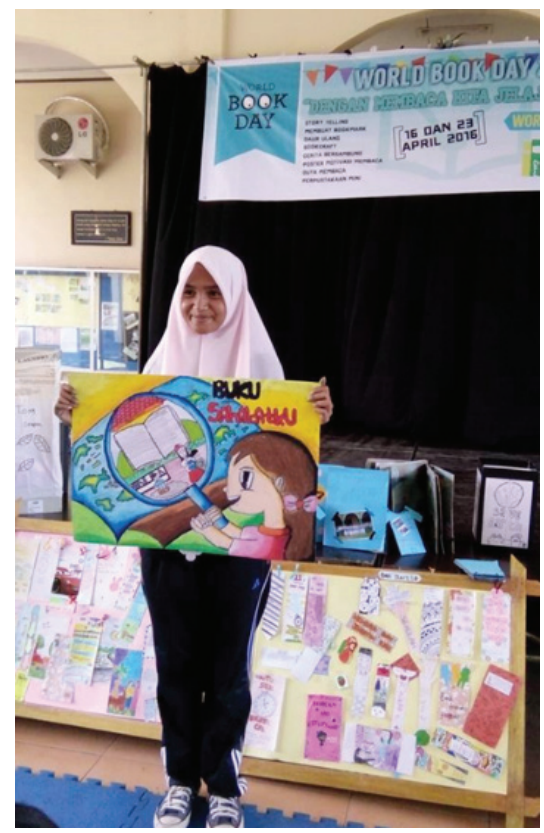

Figure 10: Students presenting their poster as part of Reading Campaign 
This borrowing does not include text books which is provided in the school library. When Sukma Bangsa School Librarian presented the data during annual meeting, school leaders and teachers are very concerned about how little Library and literacy featured as part of learning process in the school. Therefore, Librarian and teachers decided to create several literacy activities and reading campaign supported by School Directors and Principals for the next school year. The following pictures shows Reading Circle for elementary students and World Book Day celebration where various literacy-related activities done to promote reading culture in our school.

Data-based decision making helps school to focus on what really matters in learning and provided relevant information to support this decision. SISTO in Sukma Bangsa School provide valuable data that will shed light on important trends which assist teachers and school leaders to set their priorities. Data also help school managers to allocate resources and support activities relevant to learning process and positive school culture development.

\section{Teacher performance application}

SISTO also supports teacher learning through its Teachers Performance framework featured in SIMAKA. A recent addition

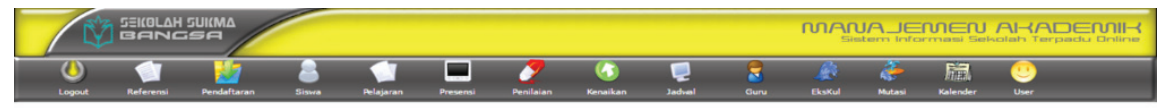

Guru

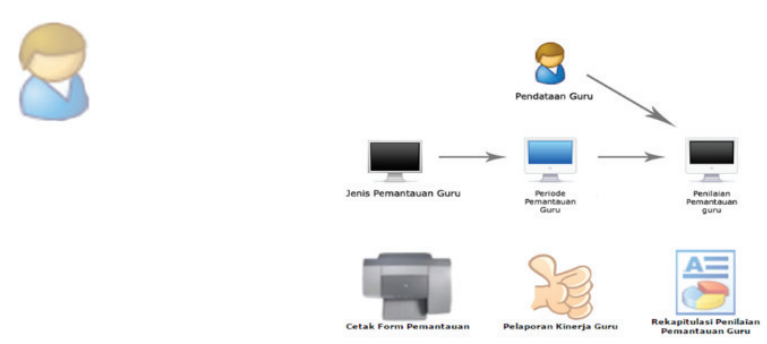

Figure 11: Screenshot of Teachers Performance Framework 


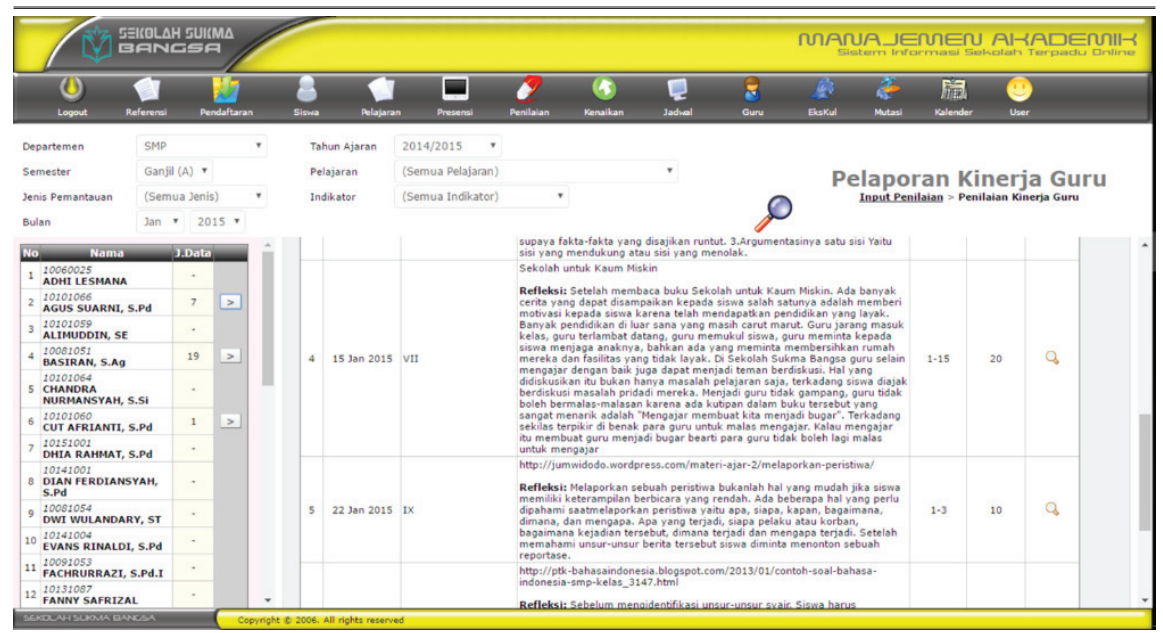

Figure 12: Screenshot of teachers reading reflection

in the application, the framework allows Principals, teachers and Counsellors to put data that record teachers' performance and used it as basis for teachers' evaluation. The application consists of four aspects namely personal competence, pedagogical competence, professional competence and social competence. In this article we will focus on two competences that require daily practices of teachers learning supported by SISTO namely professional competence and social competence.

Professional competence in Sukma Bangsa School is interpreted as teachers' effort to improve their capabilities through individual effort such as reading and writing. For performance in this aspect, teachers are required to track their reading activities in the reading log including their reflections on the reading materials. This reading log might include description on how certain materials compliment their lesson planning. Sample of teachers' reading log can be seen at Figure 12 .

Another aspect of the teachers' performance evaluation is Social Competence. For this aspect, teachers are required to put in data for their class project and guest lecture. This is an interpretation of teachers' social competence which shown by how they collaborate with other teachers and people from outside of 


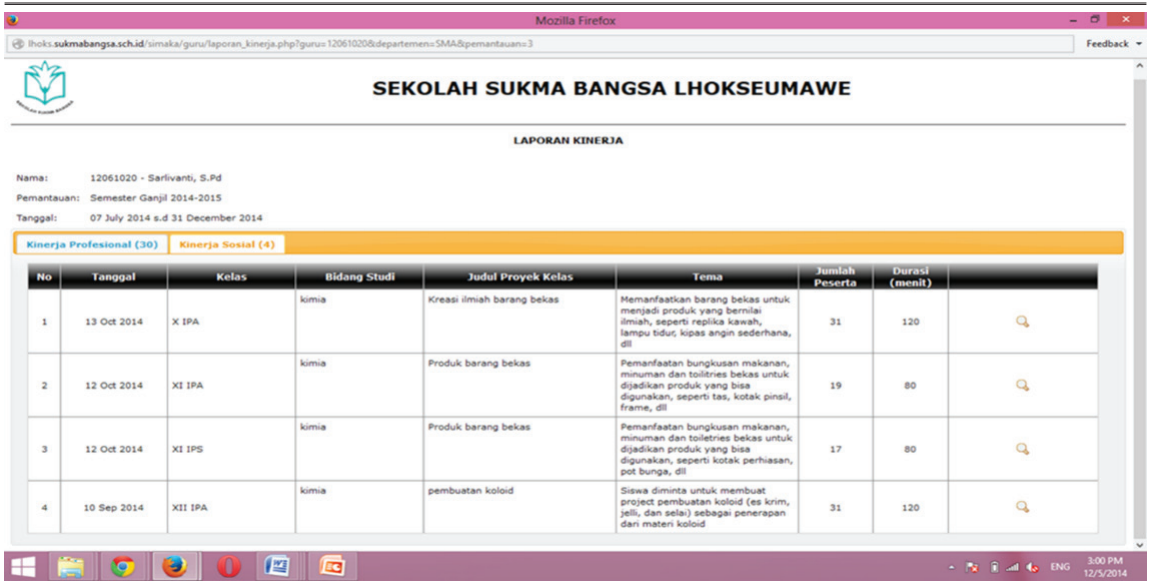

Figure 13: Screenshot of teachers community-based learning

the school in classroom session or class projects. Figure $\mathbf{1 3}$ is a screenshot of various class projects and guest lectures invited by a certain teacher.

Through this teachers' performance application, teachers learning is further supported through daily practice of reading and writing as well as collaborating integrated to teachers' daily activities. The framework encourage teachers to learn individually as well as collectively which in turn will strengthened professional learning community in the school.

\section{Conclusion and Suggestion}

Nowadays, teacher professional development can take many shape and forms, it can be conducted formally and informally. Training and workshop, as formal professional development activities, can be enhanced through professional learning community at the school level. The advance of ICT indicates possibilities to support teacher learning on the job through SIS and ease of access. In this article, SISTO support on informal learning at the school level by supporting reflection, collaboration and data-based decision making is briefly described. However, the effects of SISTO on teacher learning and what factors contribute to effective used of SISTO as a tool will need further investigation. 
Implementation of SIS at existing school organization needs careful consideration and considerable planning. SISTO implementation for the past ten years in Sukma Bangsa School will provide opportunities for longitudinal study of this process. The possibility of identifying organizational factors that contribute to SIS implementation is crucial to its benefits. According to Wayman (2005) school culture and leadership are among two organizational factors that might influence SIS utilization in school. He further insisted that the presence of SIS alone will not be enough to ensure its usage. Hence more research is needed to capture organizational best practices that support widespread use of it by teachers.

Challenges in using SIS may varied from school to school and how this challenges are being met will significantly influence SIS function. Therefore further investigation will need to be conducted which includes descriptions of challenges in using SIS based on Sukma Bangsa Schools experience. The research is significant to make sure that School Information System (SIS) available today can be designed one step further from gathering and managing data, to eventually support teacher learning and school development as a learning organization. 


\section{BIBLIOGRAFI}

Alam, S., Bahar, E., Santoso, S. B., \& Yudha, Y. H. (2006). Panduan Sistem Informasi Sekolah Terpadu Online (SISTO) Sekolah Sukma Bangsa. Jakarta: Yayasan Sukma.

Borko, H. (2004). Professional Development and Teacher Learning: Mapping the Terrain. Educational Researcher, 33 (3).

Kowalski, T., Lasley, T. I., \& Mahoney, J. (2008). Data-driven decisions and school leadership : best practices for school improvement. Boston: Pearson Education.

Meirink, J. A., Meijer, P. C., \& Verloop, N. B. (2009, August). How do teachers learn in the workplace? An examination of teacher learning activities. European Journal of Teacher Education, 32(3), 209-224.

Sumintono, B., \& Subekti, N. (2014). Teachers in Service Training and Retraining in Indonesia. In K. G. Karras, International Handbook of Teacher Education: Training and Re-training Systems in Modern World. Cyprus: HM Studies \& Publishing.

Telem, M. (1996). MIS Implementation in Schools: A systems socio technical framework. Computer Education, 85-93.

Visscher, A. J. (2001). Information Technology in Educational Management as Emerging Discipline. In A. J. Visscher, Information Technology in Educational Management (pp. 291296). Kluwer Academics Publishers.

Visscher, A. J., \& Fung, .. A. (2001). Imperatives for Successful Implementation of School Information Systems. In A. Visscher, Information Technology in Educational Managemen (pp. 115133). Kluwer Academic Publishers.

Wayman, J. C. (2005). Involving Teachers in Data-Driven Decision Making: Using Computer Data Systems to Support Teacher Inquiry and Reflection. Journal of Education for Students Place at Risk, 10 (3), 295-308.

Wopereis, I. G., Sloep, P. B., \& Poortman, S. H. (2010, September). Weblogs as instruments for reflection on action in teacher education. Interactive Learning Environment, 18(3), 245-261. 